\title{
Improving the Competitiveness of Agricultural Products Is the Basis for Food Security in Kazakhstan
}

\author{
Ukilyay Kerimova $^{1}$, Gaukhar Rakhimzhanova ${ }^{1}$, Assanov Beibit ${ }^{1}$ \& Yeqizbaeva Gulnur ${ }^{1}$ \\ ${ }^{1}$ Kazakh National Agrarian University, Kazakhstan \\ Correspondence: Ukilyay Kerimova, Abai av., 8, Almaty, 050100, Kazakhstan.
}

Received: January 26, 2015 Accepted: April 29, 2015 Online Published: July 30, 2015

doi:10.5539/ass.v11n19p143 URL: http://dx.doi.org/10.5539/ass.v11n19p143

\begin{abstract}
This article describes the main economic indicators characterizing the level of food security of the Republic of Kazakhstan for the years of its independence. The conducted analysis led to the conclusion that the country is strongly dependent on the imports of most types of food.

Despite significant progress in the development of the agro-industrial complex of the Republic of Kazakhstan for the years of independence, the level of competitiveness of agricultural products is still low. The main limiting factors, according to the author, are: fragmentation of economic units, technical and technological backwardness of the industry; insufficient level of compliance of agricultural products with modern quality standards; low profitability of agricultural production. The article defines the main directions and forms of improving the competitiveness of agricultural products in Kazakhstan as a fundamental factor in ensuring food security of the country.
\end{abstract}

Keywords: agro-industrial complex (AIC), import substitution, food security, competitiveness, export potential

\section{Introduction}

The determining factor of the countries integration under modern conditions is competition from global producers of goods and services. Every year the value of this dominant becomes more and more like a global challenge for the Republic of Kazakhstan and other EAEC partner countries (Umarov, 2014, pp. 610-614).

In the late 90s, Kazakhstan's economy has lost major market positions, being unable to compete with the mass production of foreign producers. A similar situation pertains to the sectors of agro-industrial complex, which are directly involved in the production of essential foods.

The transition to market relations in fact led to the collapse of the former system of interconnections and economic relations of agricultural enterprises with the food and processing industries. Destruction of trade, industrial and economic, financial and economic relations led to the fall of agricultural production and food industry, increase in import dependence and reduction in the level of food consumption. All this aggravated the problem of food security in the country.

Gradual recovery of the Republic of Kazakhstan AIC began in 2000s: there was an increase in gross agricultural production, the cultivated area of major crops began to expand, the decline in cattle numbers stopped. The volume of foreign trade in agricultural raw materials and food products began to grow. However, the export growth lagged compared to the import growth, which resulted in Kazakhstan becoming a net importer of agricultural products.

In recent years, the agricultural sector of the Republic of Kazakhstan has somewhat improved, primarily due to increased state support for rural commodity producers. The country population increases, which provides intensive growth of food consumption with a change in consumption patterns in favour of higher-quality food.

Currently, the agricultural sector of the Republic of Kazakhstan has great potential for export. However, this potential is not implemented in full. There are still a number of unresolved problems of the AIC, which pose threat to food security in Kazakhstan; the main problems are low profitability of agricultural production, weak food base, insufficient level of development of the food and processing industry, poor logistics of the agricultural system, dependence on food imports and others.

The achieved level of AIC development in Kazakhstan, based on traditional techniques of production and 
processing of agricultural raw materials, does not meet the high demands of the global market. Low labour productivity in the industry, imperfection of applied technologies and small-scale production do not allow using best practices of intensive agriculture, do not provide the full use of material, labour and other resources. These factors have a negative impact on the competitiveness of domestic AIC, which can lead to the dominance of imported foreign goods under the WTO and the Customs Union, and local producers being ousted from the market (Resolution of the Government of the Republic of Kazakhstan dated February 18, 2013 No. 151, 2013).

National economic significance of the problems of increasing the AIC products competitiveness determined the relevance of this article.

\section{Methodology}

The term "food security" is used to describe a situation where the country is able to adequately feed its population at the national or regional levels. The traditional definition of food security in developing countries is the following: "Food security is a situation where all people always have physical, social and economic access to sufficient, safe and nutritious food that meets their dietary needs and food preferences for an active and healthy lifestyle" (Latruffe, 2010).

Physical accessibility is dependent on domestic production and the possibility of food imports. Domestic production is determined by the country's comparative advantage in the production of basic food products, the efficiency of this production (Serova, 2014).

To analyse the problematic moments in their socio-economic policies and the development of measures aimed at improving the situation, the food security index is used. It is developed by the research centre of the "Economist" magazine based on FAO data. The index reflects the three components of food security. A separate index is calculated for each component as a composite of several parameters. For example, physical access to food is assessed by such parameters as sufficiency of domestic production, public investments in agricultural research, development of agricultural infrastructure, political stability, etc. The parameters for estimating economic access to food are the share of expenditures on food in total household expenditures, poverty rate, availability of social assistance programs, etc. Quality of food and food safety are assessed by the following parameters: level of protein, micronutrients in the diet, diet variety, the presence of food safety control in the country, etc.

A necessary condition for economic growth and food security in the country is the competitiveness of agricultural products.

In economically developed countries the core of competition is either the macroeconomic policy or comparative advantages, provided by the presence of such sources as labour, natural resources or capital (Gizzatova, 2013, pp. 25-31). However, under modern conditions, the presence of the two latter is a necessary but not a sufficient condition for the competitiveness of the producer. Competitive products are such products that meet the demand requirements for price, quality and quantity, and make a profit for companies.

Competitiveness to a greater extent reflects the efficient use of resources by commodity producers for production. The ability of agricultural enterprises to compete and be competitive depends on economic conditions. Application of advanced technologies (e.g. disease-resistant varieties), the availability of local resources (land, human capital), infrastructure (e.g. transport and communications) can increase profitability by increasing product prices, reducing costs and increasing the efficiency of agricultural production (OECD, 2011).

The main goal of this article is to study the mechanisms of ensuring the competitiveness of agricultural products in order to improve the food security of the Republic of Kazakhstan.

The information and empirical basis of the research are laws and regulations of the Republic of Kazakhstan, the Customs and the Eurasian Economic Union, messages and decrees of the President, resolutions of the Government of Kazakhstan; official data of the Statistics Agency of the Republic of Kazakhstan and the Ministry of Agriculture of the Republic of Kazakhstan; materials published in scientific and periodical literature, on the Internet.

To achieve this goal the following scientific methods were used in the research: Economic and Statistic, monographic, abstract and logical and others.

\section{Results}

Covering an area equivalent to the size of Western Europe and having a land fund for agricultural purposes, which is about $80 \%$ of the country, Kazakhstan has significant potential to form regional and global food security. The Republic of Kazakhstan is ranked second in the world in terms of arable land per capita (1.36 ha/capita) (The World Bank, 2014) and is consistently ranked among the top ten world's largest exporters of wheat (OECD, 
2013).

Despite the fact that the Republic of Kazakhstan has great potential for the development of agriculture, the agro-industrial sector accounts for only $6.6 \%$ in the total gross national product (Committee on Statistics of the Republic of Kazakhstan, 2014).

The agro-industrial complex is one of the most important sectors of the economy of Kazakhstan and a pillar of food security of the state (Omarova, Markhayeva, Ydyrys, Abilgazieyeva, \& Duisembekova, 2014, pp. 538-542). However, the current state of the AIC and the actual pace of its development in the past 20 years allow describing the situation on the domestic food market of the country as complex and insufficiently stable.

Problems of Kazakhstan after gaining independence in 1991 - including the transition from a centrally planned economy to a market one - were huge, and the agricultural sector is no exception to this rule. The share of agriculture in Kazakhstan's GDP declined in the second half of the 1990s, which was also characteristic for other developing member countries of the OECD.

However, the value added per agricultural worker almost doubled: from $\$ 2,004$ in 1995 to $\$ 3,972$ in 2013 (The World Bank, 2014), which is an indication of real progress in overcoming the problems associated with gaining an independent statehood. In addition, for the period 1995-2014, food production per capita in Kazakhstan increased more than 12-fold (Figure 1).

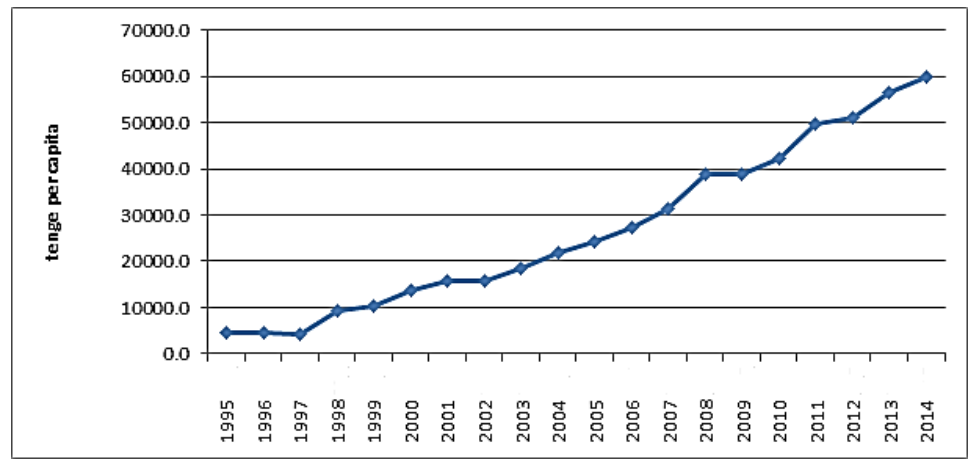

Figure. 1 Dynamics of food production in the Republic of Kazakhstan for 1995-2014, tenge per capita

Table 1. The balance of agricultural products exports and imports in the Republic of Kazakhstan in 2014, ths. US \$ ("Committee of Customs Control of the Ministry of Finance of the Republic of Kazakhstan", www.e.customs.kz/wps/portal/customs/!ut/p/b1)

\begin{tabular}{llll}
\hline Products & Exports & Imports & Surplus \\
\hline Livestock & 547.9 & $47,037.5$ & $-46,489.6$ \\
Meat and edible offal & 444.6 & $204,997.4$ & $-204,553.0$ \\
Fish and crustaceans, molluscs and others. & $72,662.6$ & $35,134.0$ & $37,528.6$ \\
Milk and milk products & $4,968.0$ & $159,378.7$ & $-154,411.0$ \\
Birds' eggs & $2,606.8$ & $1,707.6$ & 899.2 \\
Potato & 462.7 & $13,737.8$ & $-13,275.1$ \\
Other vegetables, including canned vegetables & $9,735.1$ & $225,732.4$ & $-215,997.0$ \\
Nuts & $2,165.5$ & $47,156.3$ & $-44,990.8$ \\
Fruit, including canned and dried fruit & $1,168.4$ & $533,816.8$ & $-532,648.0$ \\
Tea & $2,690.9$ & $107,633.3$ & $-104,942.0$ \\
Wheat & $556,360.1$ & 186.2 & $556,173.9$ \\
Other cereals & $153,902.1$ & $3,337.4$ & $150,564.7$ \\
Products of the milling industry & $559,917.0$ & $1,214.1$ & $558,702.9$ \\
Fats and oils of animal and vegetable origin & $61,066.9$ & $51,144.9$ & $9,922.0$ \\
Sausages and canned meat & $4,042.5$ & $1,527.4$ & $2,515.1$ \\
Canned fish & $5,146.1$ & $6,247.0$ & $-1,100.9$ \\
Sugar & $2,644.3$ & $228,277.0$ & $-225,633.0$ \\
Confectionery & $10,485.2$ & $26,216.5$ & $-15,731.3$ \\
Cocoa and its products & $18,162.4$ & $80,041.5$ & $-61,879.1$ \\
Final products from cereals grains and flour & 4773.0 & $121,588.8$ & $-73,858.8$ \\
\hline
\end{tabular}


According to the World Bank, in 2013 the productivity of agriculture in Kazakhstan amounted to $\$ 3,973$ per 1 employee and is one of the highest in Central Asia. For comparison: This indicator in Uzbekistan is \$2,183, in Tajikistan - \$1167, in the Kyrgyz Republic - \$1419 per 1 employee. However, this figure is still lower than in neighbouring Russia (\$5,973 per 1 employee) and Belarus (\$9,086 per 1 employee).

Every year, the country imports products of animal and plant origin and cooked food worth more than 4 billion US dollars. During the period 2009-2014 the imports of agricultural products increased by $75.4 \%$, while export growth over the same period was $60.2 \%$.

Current balance of exports and imports of food products in the Republic of Kazakhstan indicates a high level of import dependence in the country on imports of basic food products (Table 1).

Food independence can be maintained in case if the share of imports in domestic consumption does not exceed $20 \%$ (Buzdalov, 2012). At the same time, the share of imports of most food products types in the domestic consumption of the Republic of Kazakhstan in real terms significantly exceeds this figure (Table 2).

Table 2. Assessment of the Republic of Kazakhstan's dependence on imports on certain types of food products in 2014 , tonnes

\begin{tabular}{llll}
\hline & Domestic sales & Imports & The level of import dependence, $\%$ \\
\hline Fruits and nuts, processed and preserved & $146,676.5$ & $145,539.5$ & $99.22 \%$ \\
Milk in a solid form & $30,057.4$ & $27,070.4$ & $90.06 \%$ \\
Vegetables, processed and preserved & 87794.1 & $71,358.1$ & $81.28 \%$ \\
Milk and condensed cream & $41,823.7$ & $32,666.7$ & $78.11 \%$ \\
Fish, crustaceans & $75,821.8$ & $44,753.8$ & $59.02 \%$ \\
Poultry meat & $293,655.4$ & $159,477.3$ & $54.31 \%$ \\
Cheese and cottage cheese & $44,182.5$ & $22,283.5$ & $50.44 \%$ \\
Chocolate, confectionery products made of chocolate and sugar & $192,838.5$ & $92,149.5$ & $47.79 \%$ \\
Sausages and similar meat products & $75,891.9$ & $33,489.9$ & $44.13 \%$ \\
Butter & $26,061.1$ & $10,359.1$ & $39.75 \%$ \\
Canned meat & $109,020.3$ & $39,090.3$ & $35.86 \%$ \\
Sugar & $535,996.5$ & $160,405.5$ & $29.93 \%$ \\
Vegetable oils & $445,292.4$ & $115,812.4$ & $26.01 \%$ \\
Sunflower oil & $302,677.0$ & $67,748.0$ & $22.38 \%$ \\
\hline
\end{tabular}

In Kazakhstan, for the most part, basic consumer food products are imported, and expensive delicacies - in smaller amounts. This situation is dangerous for the country's economy: dependence on the external market only increases, competition on both domestic and foreign markets enhances. Kazakhstan provides itself and neighbouring countries with a few products, mostly with bread and cereal products. Although the production of many imported goods can be carried out within the country.

Kazakhstan supplies grain to the foreign market and is the world market leader in flour export. High demand for Kazakhstan flour is due to the high quality of grain processing. Not only traditional types of flour are exported, but also a special grind flour corresponding to the specific requirements of foreign consumers. By the volume exports of flour in recent years is comparable to the export of wheat and substantially exceeds it in terms of value. This highlights the increased attention that Kazakhstan pays to increasing the importance of agricultural production. CIS markets with a total of $71.5 \%$ say that the main share of food and agricultural exports is from Kazakhstan. In recent years Kazakhstan continues to increase exports to the EU and China.

In general, it should be noted that the food security situation in the Republic of Kazakhstan is improving: in the Global ranking of 2014, which covers 109 countries, Kazakhstan occupies the $57^{\text {th }}$ place with 53.3 points versus 52.7 points in 2013 (A report from The Economist Intelligence Unit, www.foodsecurityindex.eiu.com/Resources).

It should be noted that the general level of food security in Kazakhstan is slightly inferior to EAEU partners Russia and Belarus, but the country is far ahead of the Central Asian Cooperation (CAC). For comparison: Russia (62.7 points) was rated the 40 th, Belarus with 60.8 points - the $47^{\text {th }}$ place (Table 3 ). 
Table 3. The food security index of the member countries of EAEU and CAC

\begin{tabular}{lllll}
\hline Countries & Total GFSI-index & $\begin{array}{l}\text { Accessability } \\
\text { economic }\end{array}$ & physical & Food products security \\
\hline Kazakhstan & 53.3 & 58.2 & 42.7 & 70.3 \\
Russia & 62.7 & 70.7 & 51.2 & 74.3 \\
Belarus & 60.8 & 61.3 & 58.1 & 67.4 \\
Uzbekistan & 46 & 37.6 & 51.5 & 51.4 \\
Tajikistan & 38.7 & 37.8 & 39 & 40.2 \\
\hline
\end{tabular}

The strengths of the food security of Kazakhstan include the existence of a national program to rationalize the population nutrition; low proportion of population living below the poverty line; a sufficient level of food availability calculated kcal/capita per day, and the level of food aid; food safety; the mode of the most-favoured-nation (MFN) for tariffs on imports of agricultural products.

Experts note the following weaknesses for the food security of the Republic of Kazakhstan: insufficient level of public expenditure on research and development in the agricultural sector; instability of agricultural production; the GDP value per capita and high risks of corruption, manifested in the inefficient use of natural resources and food distribution.

\section{Discussion}

Despite significant progress in the development of the agro-industrial complex of the Republic of Kazakhstan during the years of independence, the level of competitiveness of agricultural products is still low. For example, crop yields and livestock productivity remain well below the levels reached in the countries with similar agro-ecological conditions. For example, grain yield in Kazakhstan is 5 times lower than in China, 3.6 times lower than in Canada, 1.9 times lower than in the Russian Federation (FAOStat, www.faostat3.fao.org/compare/E).

In order to exploit the full potential of agriculture, the competitiveness of the agricultural sector has to be improved by providing access to markets, know-how and technologies and related financial services to serve small farmers. As a result, the agricultural sector with limited access to international markets must find new export markets for agricultural products, which will allow increasing the economic growth.

The main limitations that affect the competitiveness of agricultural products and prevent the development of the agro-industrial complex of Kazakhstan as a whole, are as follows:

1) The fragmentation of economic units and dominance of small-scale production (i.e., the absence of vertically integrated farms). The absolute majority of players are represented by small farms that occupy a small fraction of the total area of farmland. The dominance of small-scale production creates barriers not only to the development of the agricultural sector itself, but also hinders the development of processing industries.

Reforming of agricultural enterprises and associated reallocation of production factors has led to a radical change in roles of large and small-scale production. Agricultural enterprises producing nearly two-thirds of agricultural production in the 1990s now produce only one-third. Consequently, the share of farms and households in total production increased. Farms produce $97 \%$ of raw cotton, about two-thirds of oil crops, more than $50 \%$ of meat.

2) Technical and technological backwardness of the industry

Since 1990, the amount of equipment used in agriculture of Kazakhstan decreased by more than $50 \%$. However, after 2000, the fleet of agricultural machinery gradually began to expand, partly due to the state leasing programs. However, the rate of renewal of agricultural production fixed assets remains extremely low. The replacement percentage of tractors is about $1 \%$; harvesters $-2.2 \%$; tillers - $0.1 \%$.

Moreover, the amount of investments in fixed assets of the agricultural industry in Kazakhstan remains relatively small compared to the total investment in the national economy. More than two-thirds of the total amount of investments is crop production.

Introduction of new technologies, innovations into the AIC branches, transfer of know-how to farmers is carried out very slowly. For example, from a wide range of resource-saving technologies in agriculture, as zero tillage, the introduction of new varieties of wheat, testing new methods to combat animal diseases or irrigation technologies such as drip irrigation at the national level are introduced very slowly. 
Insufficient level of compliance of agricultural products with modern quality standards.

The global trend in the agricultural sector is compliance with the standards and requirements for food safety. Many countries introduced more stringent standards and placed primary legal responsibility for ensuring food safety on commodity producers.

The fragmentation of agrarian production and food industry creates an additional problem for the formation of the modern system of food safety. Private enterprises have difficulties in the implementation of private standards to meet consumer demand. It is a complex technical, economic and social objective to control the quality and safety of agricultural products coming from small agricultural producers. For a small producer it is much more difficult to meet the high quality standards than for a large industrial producer. In addition, it is necessary to take into account the lack of the traditional culture of compliance with quality requirements.

New technical rules, including production standards at the level of the Customs Union, which will gradually replace national standards raise concern.

Many companies follow national standards that are more suited to local conditions. Regulations and technical standards, which do not take into account the peculiarities of local production, can have a negative impact on the competitiveness of Kazakh enterprises and the agricultural sector as a whole (UNECE, 2014).

Besides, despite the agreement on mutual recognition, Kazakhstan compliance certificates are not recognized by the Russian authorities. As a result, enterprises must undergo additional certification in the Russian Federation.

3) Low profitability of agricultural production

Small-scale nature of production has a negative impact on the profitability of agricultural production due to high costs per unit of output, and the share of a large part of the expenses is inversely proportional to the size of enterprises. In addition, before trade enterprises came for products themselves, but now producers are forced to go around shops and supermarkets offering goods. Thus, for the majority of companies operating in the small business sector, agricultural production is unprofitable. In such circumstances, it is difficult to compete with large foreign suppliers.

Moreover, non-compliance of the development level of the transport infrastructure with the growing needs of the market turnover of agricultural products of the Republic of Kazakhstan also contributes to high transaction, logistics (up to $60 \%$ of the total cost of production and sales) and transportation costs (up to $20 \%$ in costs, whereas in developed countries this figure equals to $8 \%$ ).

For manufacturers of perishable agricultural products (especially meat and milk), the lack of transport and storage with the maintenance of the required temperature leads to a situation where products get spoiled, sales are carried out mainly in the local market and the quality is non-uniform (OECD, 2013).

With regard to the export of grain, its final price is determined by the price on the world market. Domestic market prices are subject to change, due to the low quality of products, insufficient capacity of elevators and undeveloped railway network. For example, transportation costs for 1 tonne of production to the Black Sea or the Baltic Sea exceed \$100. Therefore, for example, export of Kazakh wheat (except high-protein and organic) to the markets of the European Union, North Africa, the Middle East via the Black Sea and Baltic ports, taking into account the cost of transportation is economically unprofitable. High transport costs lead to a collapse in prices in the domestic market and as a consequence - to unprofitability of agricultural production. Paradoxically, farmers suffered losses in case of high yields.

The state of internal roads makes it difficult for producers to participate in modern supply chains, as a result they are forced to sell their products to a single buyer on the local market or to resellers at a price assigned by them.

In addition to the "hard" market infrastructure (roads, ports and elevators) and the "soft" infrastructure, which includes market information, system of knowledge and specialized training, contractual relationships, bureaucratic procedures, a regulatory system in the field of collective action and competition, also requires improvements. Lack of development of these systems increases the cost of all the participants of the product chain.

According to the expert community, the most important aspect of Eurasian integration is the industrialization of AIC branches, with emphasis on the existing natural potential and competitive advantages of the countries.

The Republic of Kazakhstan has powerful resource potential and unique advantages to develop this sector, which include the following:

- Low density of agricultural production in Kazakhstan provides natural organic character to the sector; 
- The sector has the advantages of natural global compliance with the requirements of environmental and food safety. Kazakhstan ranks first in the world in terms of the lowest levels of fertilizer application in crop production (only 0.1 tonnes per hectare of cultivated areas);

- Total area of agricultural land in Kazakhstan is 222.6 million hectares, which amounts to $82 \%$ of the country.

- Due to the large extent of the territory, in Kazakhstan there is a large range of climatic conditions, which helps to diversify agricultural production in different areas, for example, conditions of the northern region are particularly favourable for grain production, the central region - livestock and the southern territory - rice production and cultivation of fruits and vegetables.

- The ever-increasing demand for food on the main markets, geographically located close to Kazakhstan (China, Central Asia, Russia).

- Developing logistics infrastructure and a unique location of Kazakhstan between the main markets of food consumption - China, Russia, the Middle East and Europe.

We can single out the following directions as the priority directions, helping to improve the competitiveness of agricultural products of the Republic of Kazakhstan on foreign and domestic markets:

- Association of small farms.

Achieving the high level of competitiveness has greatly contributed to creation of an environment which stimulates association of small farms and associated work of agricultural producers' consumer cooperatives with processors of agricultural products. Preservation of tax breaks, subsidies and low-interest loans can effectively contribute to this association.

- Development of organic animal husbandry.

Kazakhstan is ranked 5th in the world in terms of pasture resources. However, only about $30 \%$ of pastures were used for grazing in recent years due to lack of water reserves and remote locations far from settlements. Thus, it would be appropriate to develop pastoral farming and organic animal husbandry through the development of pasture resources (Seidumanova, 2013). Development of a centralized system of veterinary control with the use of best practices can contribute to improvements in the competitiveness of organic domestic products.

- Reduction of production costs.

In order to support Kazakh producers of food industry it is necessary to implement measures aimed at reducing the costs on utilities, certification and accreditation through the adoption of legal documents. Grants and subsidies for farmers can be used as additional measures to reduce costs and increase competitiveness.

- Improving production technologies.

Through the scientific modernization of agriculture, industrial processing and increase R\&D funding it is necessary to improve the production technology of the food industry. It is also necessary to increase the availability of educational and consulting services for all groups and categories of agricultural producers.

- Building a strong national brand.

Crop and livestock production are traditional industries of Kazakhstan and there is a considerable potential for the creation and promotion of national brands, such as "Bread of Kazakhstan" and "Meat of Kazakhstan". Creation of an ecologically pure grain brand will ensure high demand for grain and flour produced in Kazakhstan, meat processing products and will have a positive impact on the image of the country. Huge possibilities open up on the Russian market, especially after the imposition of sanctions. It is assumed that in addition to grain and meat, the Russian entrepreneurs will also buy Kazakh potato, which can replace the vegetables that were previously imported from Poland.

\section{Conclusion}

Thus, the development of the AIC in Kazakhstan has clear competitive advantages that should be fully implemented in order to improve the overall performance of the industry. Improving the competitiveness of agricultural products can be a significant additional source of production growth and import substitution, which ultimately will increase the country's food security. At the same time, it is necessary to carry out continuous monitoring of the shortcomings in the industry development in order to overcome them on a sustained basis and eliminate them.

\section{References}

A report from The Economist Intelligence Unit. Global food security index. (2014). An annual measure of the 
state of global food security. Retrieved April 24, 2015, from http://foodsecurityindex.eiu.com/Resources

Buzdalov, I. (2012). Agrarian policy and the economy of Russia: View in the light of world globalization processes. AIC: regions of Russia, 1, 1-6.

Committee on Statistics of the Republic of Kazakhstan. (n. d.). Official statistics on the agricultural sector. Retrieved April 24, 2015, from http://www.stat.gov.kz/faces/wcnav_externalId/homeNumbersAgriculture? _afrLoop=1033248328086051\#\%40\%3F_afrLoop\%3D1033248328086051\%26_adf.ctrl-state\%3D4icqpqsa p_37

Customs Control Committee of the Ministry of Finance of Kazakhstan. Indicators of Foreign Trade. (n. d.). Retrieved April 24, 2015, from http://e.customs.kz/wps/portal/customs/!ut/p/b1

FAOStat. (n. d.). Retrieved April 24, 2015, from http://faostat3.fao.org/compare/E

Gizzatova, A. (2013). Problems in the theory of supply and demand on the agricultural and food market of the Republic of Kazakhstan. Economics and Statistics, 3, 25-31.

Latruffe, L. (2010). Competitiveness, Productivity and Efficiency in the Agricultural and Agri-Food Sectors. OECD Foud, Agriculture and Fisheries Papers, 30, 63. INRA-AgrocampusOuest, Rennes, France. http://dx.doi.org/10.1787/5km91nkdt6d6-en

OECD Review of Agricultural Policies: Kazakhstan. (2013). Retrieved April 24, 2015, from http://www.oecd.org $/ \mathrm{tad} /$ agriculturalpolicies/kazakhstan-review-2013.htm

OECD. (2011). Fostering Productivity and Competitiveness in Agriculture. OECD Publishing.

OECD. Review of the Agricultural Policy: Kazakhstan 2013. (2013). Retrieved April 24, 2015, from http://www.keepeek.com/Digital-Asset-Management/oecd/agriculture-and-food/oecd-review-of-agricultural -policies-kazakhstan-2013_9789264202443-ru\#page3

Omarova, G., Markhayeva, B., Ydyrys, S., Abilgazieyeva, Z., \& Duisembekova, G. (2014). Problems of development of agro-industrial complex in the system of food security control. Life Science Journal, $11(12 \mathrm{~s}), 538-542$.

Resolution of the Government of the Republic of Kazakhstan No. 151 "On approval of the Programme for the development of agriculture in the Republic of Kazakhstan for 2013-2020 "Agribusiness 2020" - IRS "Adilet". (2013, February 18). Retrieved April 24, 2015, from http://adilet.zan.kz/rus/docs/P1300000151

Seidumanova, M. (2013, June 13). Prospects for the development of food industry in Kazakhstan. KURSIV, 23(500).

Serova, E. (n. d.). Food security of Central Asia countries. The official website of the Russian Council on Foreign Affairs. Retrieved April 24, 2015, from http://russiancouncil.ru/inner/?id_4=3765\#top

The World Bank. (n. d.). IBRD-IDA. Arableland (hectaresperperson). Official Site of the World Bank Group. Retrieved April 24, 2015, from http://data.worldbank.org/indicator/AG.LND.ARBL.HA.PC/countries/all? display $=$ default

The World Bank. IBRD-IDA. Agriculture value added per worker (constant 2005 US\$). (n. d.). Official Site of the World Bank Group. Retrieved April 24, 2015, from http://data.worldbank.org/indicator/AG.LND.ARBL. HA.PC/countries/all?display $=$ default

Umarov, I. (2014). Scientific aspects of economic mechanisms of grain production development based on innovations. Life Science Journal, 11(10), 610-614.

United Nations Economic Commission for Europe. Regulatory and procedural barriers to trade in Kazakhstan. (2014). Retrieved April 24, 2015, from http://www.unece.org/fileadmin/DAM/trade/Publications/ECETRADE_407E-Kazakhstan.pdf

\section{Copyrights}

Copyright for this article is retained by the author(s), with first publication rights granted to the journal.

This is an open-access article distributed under the terms and conditions of the Creative Commons Attribution license (http://creativecommons.org/licenses/by/3.0/). 